\title{
PERBEDAAN HASIL BELAJAR DAN AKTIVITAS SISWA MENGGUNAKAN MODEL PEMBELAJARAN KOOPERATIF TIPE JIGSAW DENGAN NHT PADA MATERI SISTEM PERNAPASAN MANUSIA
}

\author{
Risa Utami ${ }^{1}$, Erlintan Sinaga ${ }^{2}$, dan Herawati Dongoran ${ }^{3}$ \\ ${ }^{1,2}$ Program Studi Pendidikan Biologi, FMIPA, Universitas Negeri Medan, Jl. Willem Iskandar Psr. V Medan Estate, \\ Medan, Indonesia, 20221 \\ ${ }^{3}$ Guru Biologi MAN 1 Medan, Jl. Willem Iskandar No. 7B, Medan Tembung, Kota Medan, 20222 \\ *E-mail : risautami150796@gmail.com
}

\begin{abstract}
Abstrak
Penelitian ini bertujuan untuk mengetahui perbedaan hasil belajar dan aktivitas siswa menggunakan model pembelajaran kooperatif tipe Jigsaw dengan NHT pada materi sistem pernapasan manusia di kelas XI IPA MAN 1 Medan T.P 2017/2018. Jenis penelitian ini adalah penelitian eksperimen semu. Sampel dalam penelitian ini terdiri dari 2 kelas yaitu kelas XI IPA ${ }^{2}$ menggunakan model pembelajaran kooperatif tipe Jigsaw dan kelas XI IPA $^{4}$ menggunakan tipe NHT. Hasil analisis data menunjukkan rata-rata hasil belajar menggunakan model Jigsaw sebesar 79,78 dengan SD 8,50 dan hasil belajar model Numbered Head Together (NHT) sebesar 85,52 dengan SD 7,98. Nilai aktivitas siswa pada kelas Jigsaw diperoleh sebesar 84,67 diklasifikasikan dalam kategori baik dengan nilai SD 9,26, sedangkan nilai aktivitas siswa pada kelas NHT diperoleh sebesar 88,29 diklasifikasikan dalam kategori sangat baik dengan SD 7,68. Analisis hasil belajar menggunakan uji-t pada taraf signifikan 0,05 , diperoleh $t_{\text {hitung }}>t_{\text {tabel }}(3,48>1,665)$ sehingga dalam penelitian ini hipotesis nol $(\mathrm{HO})$ ditolak dan hipotesisi alternative (Ha) diterima, analisis aktivitas siswa dengan menggunakan uji-t pada taraf signifikan 0,05 , diperoleh $t_{\text {hitung }}>t_{\text {tabel }}(2,13$ $>1,665)$ maka Ha diterima dan $\mathrm{HO}$ ditolak, dengan demikian diperoleh kesimpulan bahwa ada perbedaan hasil belajar dan aktivitas siswa menggunakan model pembelajaran kooperatif tipe Jigsaw dengan NHT pada materi sistem pernapasan manusia di kelas XI IPA MAN 1 Medan T.P 2017/2018.
\end{abstract}

Kata kunci : Hasil belajar, aktivitas siswa, Jigsaw, NHT (Numbered Head Together).

\section{Abstract}

The aim of this research to know the defferentation of students score learning and activities students using cooperative model Jigsaw with Numbered Head Together (NHT) on respiration system material of human body in class XI IPA MAN 1 Medan T.P 2017/2018. The research method used was quasi experimental research. The sampel in this research consist of 2 classes that class XI IPA ${ }^{2}$ using cooperative learning model Jigsaw and class XI IPA ${ }^{4}$ using cooperative learning model NHT. The result of data analysis shows the average of learning result using Jigsaw model of 79,78 with SD 8,50 and result of learning model Numbered Head Together (NHT) equal to 85,52 with SD 7,98. The value of student activity in Jigsaw class was obtained at 84,67 classified in good category with SD 9,26, while student activity value in NHT class obtained was 88,29 classified in very good category with SD 7,68. Analysis of learning result by using t-test at significant level 0,05 , obtained $t_{\text {count }}>t_{\text {table }}$ $(3,48>1,665)$ so that in this research null hypothesis (HO) rejected and alternative hypothesi (Ha) accepted, Analysis of student activity with using t-test at a significant level of 0,05 , obtained $t_{\text {count }}>t_{\text {table }}(2,13>1,665)$ then $\mathrm{Ha}$ accepted and $\mathrm{HO}$ rejected, thus obtained the conclusion that there are differences of learning result and activities student's using cooperative learning model Jigsaw with NHT on respiration system material of human in class XI IPA MAN 1 Medan T.P 2017/2018.

Keywords : Learning Results, Activities Student, Jigsaw, Numbered Head Together (NHT).

\section{PENDAHULUAN}

Hasil observasi dan wawancara yang dilakukan terhadap 7 siswa (perwakilan tiap kelas XI IPA MAN 1 Medan), menunjukkan bahwa 64\% guru kelas XI IPA ketika mengajar biologi dengan menggunakan metode ceramah. Metode ceramah ini bersifat teacher centered atau berpusat pada guru yang menyebabkan siswa cenderung lebih pasif di dalam kelas. Selain itu, juga akan menyebabkan siswa malas berpikir dalam mengembangkan pengetahuannya secara mandiri. Hasil wawancara tersebut juga diperoleh bahwa 71\% siswa kelas XI IPA menganggap mata pelajaran biologi merupakan mata pelajaran yang sangat membosankan, sulit dan banyak mencakup istilahistilah ilmiah yang harus dihapal. Sedangkan berdasarkan hasil wawancara dari guru biologi kelas XI IPA MAN 1 Medan, diperoleh bahwa ketika proses belajar mengajar berlangsung di dalam kelas siswa cenderung lebih pasif. Keadaan di dalam 
kelas memang kondusif, akan tetapi $42 \%$ siswasiswanya ada yang mengantuk, main HP, dan mengerjakan aktivitas lainnya yang tidak berhubungan dengan pelajaran biologi. Hal ini tentu akan berpengaruh pada hasil belajar siswa pada mata pelajaran biologi yang masih belum mencapai Kriteria Ketuntasan Minimal (KKM) yang telah ditetapkan di sekolah, yaitu 83. KKM mata pelajaran biologi yang telah ditetapkan MAN 1 Medan cukup tinggi, sehingga menyebabkan siswa sulit untuk memperoleh nilai di atas dari KKM.

Salah satu cara untuk menjadikan siswa lebih aktif ketika di dalam kelas sehingga mendapatkan pemahaman materi yang baik, dapat dilakukan dengan menggunakan model pembelajaran kooperatif (cooperatif learning). Pembelajaran kooperatif ini akan membuat siswa lebih mudah untuk memahami materi yang dipelajari dan dapat memecahkan materi yang menurut mereka sulit secara bersama-sama dengan diskusi kepada temannya (Trianto,2009). Selain itu, siswa juga mampu menghadapi berbagai persoalan, mampu menyelesaikan dengan tepat, dan mengaplikasikan dalam kehidupan sehari-hari (Hasruddin, 2009).

Model pembelajaran kooperatif yang digunakan dalam penelitian ini adalah tipe Jigsaw dan tipe Numbered Head Together (NHT). Model pembelajaran kooperatif tipe Jigsaw ini menekankan pada keaktifan siswa. Berdasarkan hasil penelitian Putra dan Hartati (2014), menyatakan bahwa model pembelajaran kooperatif tipe Jigsaw dapat meningkatkan hasil belajar siswa sebesar 17,06 \% dengan rincian nilai $t$ hitung sebesar 8,016 > t tabel dengan nilai sebesar 1,699 dalam taraf signifikan sebesar 0,05. Sedangkan menurut Wahyuningsih dan Murwani (2015), dalam penelitiannya menyatakan bahwa penerapan model pembelajaran kooperatif tipe Numbered Head Together (NHT) dapat meningkatkan hasil belajar kognitif siswa dengan peningkatan nilai gain pada siklus I sebesar 0,08 yang berada pada kategori rendah menjadi naik pada siklus II dengan nilai 0,43 yang telah mencapai kategori sedang dengan peningkatan sebesar 0,35. Selain itu, di dalam penelitian Dwi dan Singgih (2015), juga menyatakan bahwa penerapan model pembelajaran kooperatif tipe Numbered Head Together (NHT) dapat meningkatkan aktivitas siswa pada saat pembelajaran dengan peningkatan nilai pada siklus I rata-rata memperolah sebesar $71,43 \%$ yang berada pada kategori sedang menjadi naik pada siklius II dengan nilai sebesar $80,52 \%$ yang telah mencapai kategori baik dengan peningkatan 9,09\%.

Mata pelajaran biologi terdapat materi sistem pernapasan pada manusia yang mencakup tentang alat pernapasan, mekanisme pernapasan, frekuensi pernapasan, pertukaran oksigen dan karbondioksida, volume udara dan kapasitas paruparu serta penyakit atau kelainan yang terjadi pada sistem pernapasan manusia. Peneliti memilih materi sistem pernapasan pada manusia ini dikarenakan berdasarkan hasil wawancara dengan guru biologi di kelas XI IPA MAN 1 Medan, diperoleh bahwa materi sistem pernapasan ini pada tahun sebelumnya terdapat $46 \%$ siswa yang memperoleh nilai di bawah KKM, yaitu 70-80. Selain itu, hasil wawancara yang dilakukan dengan 7 siswa mengenai materi sistem pernapasan manusia bahwa $80 \%$ siswa hanya mampu menjelaskan arti dari pernapasan dan organ-organ yang terlibat pada pernapasan saja. Hal ini dikarenakan materi ini cukup sulit untuk dipahami, terutama pada bagian mekanisme, pertukaran gas oksigen dan karbondioksida serta volume dan kapasitas paruparu pada manusia.

Berdasarkan uraian di atas timbul permasalahan dalam penelitian ini, bagaimana perbedaan hasil belajar dan aktivitas siswa dengan menggunakan model Jigsaw dan Numbered Head Together (NHT) dalam materi sistem pernapasan manusia. Menanggapi masalah tersebut, maka akan dilakukan penelitian eksperimen yang berjudul "Perbedaan Hasil Belajar dan Aktivitas Siswa menggunakan Model Pembelajaran Kooperatif Tipe Jigsaw dengan NHT pada Materi Sistem Pernapasan Manusia di Kelas XI IPA MAN 1 Medan T.P 2017/2018".

\section{METODE PENELITIAN}

Penelitian ini dilaksanakan di MAN 1 Medan Jalan William Iskandar No.7B, Bantan Tim, Medan Tembung, Kota Medan, Provinsi Sumatera Utara 20222. Waktu penelitian dimulai pada bulan Maret - Mei 2018. 
Populasi dalam penelitian ini adalah seluruh siswa kelas XI IPA MAN 1 Medan T.P 2017/2018 yang terdiri dari 7 kelas dengan jumlah siswa 317 orang. Sampel penelitian ini adalah kelas XI IPA2 yang berjumlah 46 orang (kelas yang menggunakan model pembelajaran kooperatif tipe Jigsaw) dan kelas XI IPA4 yang berjumlah 46 orang (kelas yang menggunakan model pembelajaran kooperatif tipe NHT). Teknik pengambilan sampel dilakukan dengan random sampling (teknik pengambilan sampel secara acak sederhana).

Jenis penelitian yang dilakukan dalam penelitian adalah jenis penelitian eksperimen semu. Adapun rancangan yang digunakan dalam penelitian ini yaitu Non-Equivalent Control Group Design, dimana terdapat dua kelompok perlakuan yang kemudian diberikan pre-test untuk mengetahui kemampuan awal dan diberikan posttes setelah pembelajaran untuk mengetahui kemampuan siswa setelah perlakuan.

Variabel bebas dalam penelitian ini adalah pembelajaran menggunakan model Jigsaw dan NHT. Sementara variabel terikatnya adalah hasil belajar dan aktivitas siswa pada materi sistem pernapasan manusia.

Langkah-langkah dalam penelitian ini terdiri atas tahap persiapan, pelaksanaan dan analisis data. Tahap persiapan meliputi mengunjungi lokasi penelitian dan menentukan populasi. Tahap pelaksanaan meliputi menentukan sampel, memberikan pre-test yaitu tes yang dilakukan untuk mengetahui kemampuan awal siswa, memberikan perlakuan mengajar kepada kelas eksperimen pertama menggunakan model Jigsaw dan kelas eksperimen kedua menggunakan model NHT, Observer melakukan pengamatan terhadap aktivitas belajar siswa pada kedua kelas eksperimen, memberikan post-test yaitu tes yang dilakukan untuk mengetahui kemampuan akhir siswa mengenai sistem pernapasan manusia yang telah dipelajari. Langkah Model Jigsaw : (a) Siswa dibagi atas beberapa kelompok (tiap kelompok anggotanya 5-6 orang); (b) Materi pelajaran diberikan kepada siswa dalam bentuk teks yang telah dibagi-bagi menjadi beberapa sub bab; (c) Setiap anggota kelompok membaca sub bab yang ditugaskan dan bertanggung jawab untuk mempelajarinya. Misalnya, jika materi yang disampaikan mengenai sistem ekskresi. Maka seorang siswa dari satu kelompok mempelajari tentang ginjal, siswa yang lain dari kelompok satunya mempelajari tentang paru-paru, begitu pun siswa lainnya mempelajari kulit, dan lainnya lagi mempelajari hati; (d) Anggota dari kelompok lain yang telah mempelajari sub bab yang sama bertemu dalam kelompok-kelompok ahli untuk mendiskusikannya; (e) Setiap anggota kelompok ahli setelah kembali ke kelompoknya bertugas mengajar teman-temannya; (f) Pada pertemuan dan diskusi kelompok asal, siswa-siswa dikenai tagihan berupa kuis individu. Langkah model NHT: (a) Fase penomoran, siswa dibagi ke dalam kelompok 5-6 orang dan kepada masing-masing anggota diberi nomor; (b) Fase mengajukan pertanyaan, guru mengajukan sebuah pertanyaan kepada siswa; (c) Fase berpikir bersama, siswa menyatukan pendapatnya terhadap jawaaban jawaban pertanyaan itu dan meyakinkan tiap anggota dalam timnya mengetahui jawaban tim; (d) Fase menjawab, guru memanggil suatu nomor tertentu kemudian siswa yang nomornya sesuai mengacungkan tangannya dan mencoba menjawab pertanyaan seluruh kelas.

Instrumen yang digunakan dalam penelitian ini yaitu tes berbentuk soal pilihan berganda sebanyak 30 butir soal. Instrumen ini digunakan untuk mengetahui hasil belajar siswa yang diajarkan dengan model pembelajaran kooperatif tipe Jigsaw dan tipe Numbered Head Together (NHT). Tes ini diberikan sebanyak dua kali, yaitu tes kemampuan awal (pretest) dan tes kemampuan akhir (postest). Instrumen lembar observasi yang digunakan dalam penelitian ini untuk mengukur aktivitas siswa selama proses pembelajaran berlangsung. Observasi dilakukan dengan bantuan empat rekan peneliti sebagai observer.

Untuk menentukan nilai hasil belajar diperoleh dengan menjumlahkan soal yang benar dibagi jumlah soal keseluruhan dikali 100. Untuk menentukan nilai aktivitas diperoleh dengan menjumlahkan skor aktivitas belajar siswa dibagi 
jumlah skor seluruhnya dikali 100. Kemudian ditentukan mean, simpangan baku dan standar deviasi. Sebelum memasuki uji hipotesis, data terlebih dahulu melewati uji prasyarat data menggunakan uji normalitas dan uji homogenitas. Untuk uji normalitas digunakan uji Lillefors dan uji homogenitasnya menggunakan uji $F$ untuk menguji kesamaan varians. Dalam menguji hipotesis digunakan uji t untuk melihat perbedaan nilai ratarata kelas sampel (Sudjana 2002).

Peningkatan hasil belajar siswa dalam penelitian ini dapat dihitung dengan rumus g faktor (gain score ternormalisasi). Rumus $g$ faktor digunakan untuk mengetahui perolehan hasil belajar siswa. Presentase peningkatan hasil belajar dapat langsung dicari dari rata-rata nilai gain seluruh siswa untuk masing-masing kelas. Rumus $g$ faktor yang digunakan menurut Jumiati, $d k k$ (2011) adalah sebagai berikut:

$$
\mathrm{N}-\text { Gain }=\frac{\text { Spost }- \text { Spre }}{\text { Smax }- \text { Smin }}
$$

\section{HASIL PENELITIAN}

Hasil pretest diketahui nilai rata-rata siswa pada kelas Jigsaw sebesar 40,89 dengan standar deviasi (SD) sebesar 9,55 sedangkan pada kelas NHT diketahui nilai rata-rata siswa sebesar 46,57 dengan standar deviasi (SD) sebesar 8,75 . Dengan uji normalitas, didapatkan bahwa nilai pretest kedua kelas berdistribusi normal. Setelah dilaksanakan pretest, pada akhir pertemuan siswa diberikan posttest dalam bentuk soal pilihan berganda sebanyak 30 butir soal dengan tujuan untuk mengetahui hasil belajar siswa. Dari data yang diperoleh hasil posttest diketahui nilai ratarata siswa kelas Jigsaw sebesar 79,78 memperoleh standar deviasi (SD) sebesar 8,50 dengan nilai terendah sebesar 60 sebanyak 2 orang dan nilai tertinggi sebesar 93 sebanyak 1 orang dan terdapat 24 orang yang mencapai KKM. Sedangkan pada kelas NHT diperoleh nilai rata-rata sebesar 85,52 memperoleh standar deviasi (SD) sebesar 7,98 dengan nilai terendah sebesar 67 sebanyak 2 orang dan nilai tertinggi sebesar 100 sebanyak 2 orang dan terdapat 31 orang yang mencapai KKM (Tabel 1 dan Gambar 1).

Tabel 1. Hasil belajar siswa kelas Jigsaw dan NHT

\begin{tabular}{|c|c|c|c|c|c|c|c|c|c|}
\hline \multicolumn{5}{|c|}{ Kelas Jigsaw } & \multicolumn{5}{|c|}{ Kelas NHT } \\
\hline Nilai Postest & $f$ & $x$ & SD & $s^{2}$ & Nilai Postest & $f$ & $X$ & SD & $s^{2}$ \\
\hline 60 & 2 & & & & 67 & 2 & & & \\
\hline 63 & 1 & & & & 73 & 2 & & & \\
\hline 67 & 3 & & & & 77 & 6 & & & \\
\hline 70 & 3 & & & & 80 & 5 & & & \\
\hline 73 & 4 & & & & 83 & 8 & 85,52 & 7,98 & 63,67 \\
\hline 77 & 2 & & & & 87 & 5 & & & \\
\hline 80 & 7 & & & & 90 & 7 & & & \\
\hline 83 & 9 & 79,78 & 8,50 & 72,17 & 93 & 5 & & & \\
\hline 87 & 10 & & & & 97 & 4 & & & \\
\hline 90 & 4 & & & & 100 & 2 & & & \\
\hline 93 & 1 & & & & & & & & \\
\hline Jumlah & 46 & & & & Jumlah & 46 & & & \\
\hline
\end{tabular}




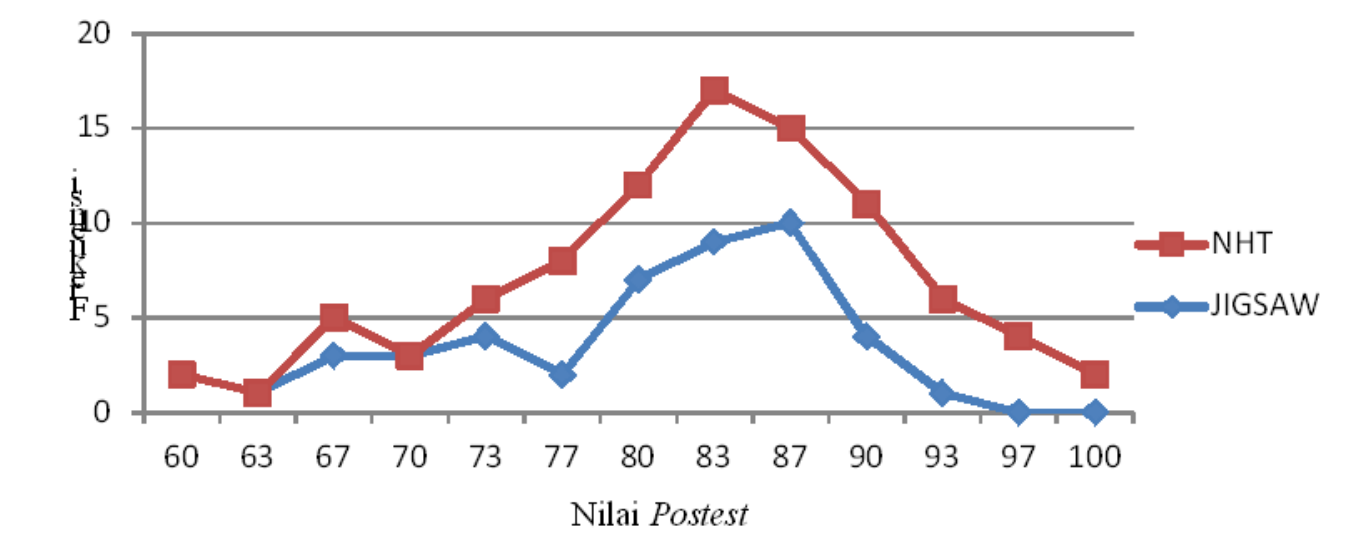

Gambar 1. Nilai Postest Kelas Jigsaw dan NHT

Berdasarkan hasil perhitungan peningkatan hasil belajar $\mathrm{N}$-Gain siswa pada kelas Jigsaw diperoleh nilai Gain sebesar 65,26\% dengan kategori sedang. Sedangkan pada kelas NHT diperoleh peningkatan nilai Gain sebesar $74,22 \%$ dengan kategori tinggi. Perbedaan peningkatan hasil belajar pada kelas Jigsaw dan NHT dapat dilihat pada Tabel 2.

Tabel 2. Peningkatan Hasil Pretest dan Postest Kelas Jigsaw dan NHT

\begin{tabular}{cccccccc}
\hline Kelas & N & \multicolumn{2}{c}{ Nilai (=op ) } & $\begin{array}{c}\text { Postest- } \\
\text { Pretest }\end{array}$ & Selisih & Gain & \%Gain \\
\cline { 3 - 5 } & & Pretest & Postest & & & \\
\hline Jigsaw & 46 & 40,89 & 79,78 & 38,89 & 59,10 & 0,6526 & $65,26 \%$ \\
NHT & 46 & 46,97 & 85,52 & 38,54 & 53,02 & 0,7422 & $74,22 \%$ \\
\hline
\end{tabular}

Penilaian aktivitas siswa dilakukan dengan menggunakan lembar observasi yang dinilai oleh 4 observer. Berdasarkan hasil yang diperoleh, nilai dari aktivitas siswa kelas NHT lebih tinggi dibandingkan kelas Jigsaw. Total nilai aktivitas siswa pada kelas NHT rata-rata 88,29 dengan kategori sangat baik sedangkan total nilai rata-rata aktivitas siswa pada kelas Jigsaw 84,67 dengan kategori baik. Aktivitas belajar yang diamati ada 4, yaitu aktivitas melihat, berbicara, mendengar, dan menulis. Perbedaan nilai aktivitas belajar siswa dapat dilihat pada (Tabel 3), yaitu:

Tabel 3. Perbedaan Nilai Aktivitas Belajar Siswa Pertemuan I, II dan III

\begin{tabular}{|c|c|c|c|c|c|c|c|c|c|c|}
\hline \multirow{3}{*}{$\begin{array}{l}\text { Aspek yang } \\
\text { diamati }\end{array}$} & \multicolumn{5}{|c|}{ Kelas Jigsaw } & \multicolumn{5}{|c|}{ Kelas NHT } \\
\hline & \multicolumn{3}{|c|}{ Pertemuan } & \multirow{2}{*}{$\begin{array}{l}\text { Skor } \\
\text { total }\end{array}$} & \multirow{2}{*}{$\begin{array}{c}\text { Rata- } \\
\text { rata } \\
\text { aktivitas }\end{array}$} & \multicolumn{3}{|c|}{ Pertemuan } & \multirow{2}{*}{$\begin{array}{l}\text { Skor } \\
\text { total }\end{array}$} & \multirow{2}{*}{$\begin{array}{c}\text { Rata-rata } \\
\text { aktivitas }\end{array}$} \\
\hline & 1 & II & III & & & 1 & II & III & & \\
\hline Melihat & 110 & 98,3 & 107,5 & 315,8 & 105,3 & 113,3 & 107,5 & 109,2 & 330 & 110 \\
\hline Berbicara & 91,7 & 98,3 & 100,0 & 290 & 96,7 & 98,3 & 99,2 & 95,0 & 292,5 & 97,5 \\
\hline Mendengar & 110,8 & 94,2 & 108,3 & 313,3 & 104,4 & 109,2 & 110,8 & 100,0 & 320 & 106,7 \\
\hline Menulis & 87,5 & 80,8 & 80,8 & 249,1 & 83 & 87,5 & 97,5 & 90,8 & 275,8 & 91,9 \\
\hline
\end{tabular}


Halaman : $158-166$

Uji normalitas dilakukan dengan menggunakan uji liliefors dengan taraf signifikan $\alpha$ $=0,05$. Syarat normal dipenuhi jika $L_{\text {hitung }}<L_{\text {tabel }}$. Hasil perhitungan uji normalitas untuk hasil belajar (postest) siswa adalah pada kelas Jigsaw, Lhitung sebesar 0,0934 dan Ltabel sebesar 0,1306 sedangkan pada kelas NHT, Lhitung sebesar 0,1217 dan Ltabel sebesar 0,1306. Dari hal diatas dapat diketahui hasil belajar siswa berdistribusi normal (Tabel 4).

Tabel 4. Hasil uji normalitas

\begin{tabular}{cccccc}
\hline No & Data & Kelas & $L_{\text {hitung }}$ & $L_{\text {tabel }}(\alpha=0.05)$ & Kesimpulan \\
\hline 1. & Pretest & Jigsaw & 0,1200 & 0,1306 & Normal \\
2. & Pretest & NHT & 0,0995 & 0,1306 & Normal \\
3. & Postest & Jigsaw & 0,0934 & 0,1306 & Normal \\
4. & Postest & NHT & 0,1217 & 0,1306 & Normal \\
5. & Aktivitas & Jigsaw & 0,1248 & 0,1306 & Normal \\
6. & Aktivitas & NHT & 0,0885 & 0,1306 & Normal \\
\hline
\end{tabular}

Pengujian homogenitas data dilakukan dengan uji F untuk hasil belajar (postest) dari kedua kelompok sampel dengan taraf signifikansi 0,05. Syarat homogen dipenuhi jika $F_{\text {hitung }}<F_{\text {tabel }}$. Hasil perhitungan uji homogenitas hasil belajar (postest) siswa adalah Fhitung sebesar 1,13 dan Ftabel sebesar 1,62. Dari hal tersebut diketahui bahwa hasil belajar siswa homogen (Tabel 5).

Tabel 5. Hasil Uji Homogenitas Data Penelitian

\begin{tabular}{ccccccc}
\hline No & Data & Kelas & Varians & Fhitung & Ftabel & Kesimpulan \\
\hline 1. & Pretest & Jigsaw & 91,21 & 1,19 & 1,62 & Homogen \\
& & NHT & 76,65 & & & Homogen \\
2. & Postest & Jigsaw & 72,17 & 1,13 & 1,62 & Homogen \\
& & NHT & 63,67 & & & Homogen \\
3. Aktivitas & Jigsaw & 85,74 & 1,45 & 1,62 & Homogen \\
& & NHT & 59,04 & & & Homogen \\
\hline
\end{tabular}

Hasil pengujian hipotesis diperoleh thitung $=3,48$ sedangkan dari daftar distribusi $\mathrm{t}$ dengan $d k=90$ dan taraf signifikan $(\alpha=0,05)$ dipeorleh harga ttabel $=1,665$. Sesuai dengan kriteria pengujian, jika thitung $>$ ttabel maka $\mathrm{Ha}$ diterima dan Ho ditolak. Sehingga dapat disimpulkan bahwa Ada perbedaan yang signifikan hasil belajar siswa menggunakan model pembelajaran kooperatif tipe Jigsaw dengan NHT pada materi sIstem pernapasan manusia DI kelas XI IPA MAN 1 Medan T.P 2017/2018.

Berdasarkan hasil perhitungan diperoleh nilai rata-rata aktivitas siswa di kelas Jigsaw sebesar 84,67 dengan kategori baik sedangkan untuk nilai aktivitas siswa pada kelas
NHT diperoleh sebesar 88,29 dengan kategori sangat baik. Maka, hasil pengujian diperoleh thitung $=2,13$ sedangkan dari daftar distribusi $\mathrm{t}$ dengan $d k=90$ dan taraf signifikan $(\alpha=0,05)$ dipeorleh harga ttabel $=1,665$. Sesuai dengan kriteria pengujian, jika thitung $>$ tabel maka $\mathrm{Ha}$ diterima dan Ho ditolak. Sehingga dapat disimpulkan bahwa Ada perbedaan yang signifikan aktivitas siswa menggunakan model pembelajaran kooperatif tipe Jigsaw dengan NHT pada Materi Sistem Pernapasan Manusia di kelas XI IPA MAN 1 Medan T.P 2017/2018. 


\section{PEMBAHASAN}

Dari hasil penelitian yang telah dilakukan dapat disimpulkan bahwa hasil belajar siswa dengan menggunakan pembelajaran model NHT lebih tinggi dari model Jigsaw pada materi sistem pernapasan manusia kelas XI IPA MAN 1 Medan T.P 2017/2018. Hal tersebut dapat dilihat dari nilai rata-rata hasil belajar dimana kelas dengan pembelajaran model Jigsaw memperoleh nilai hasil belajar sebesar 79,78 dengan $S D=8,50$, sedangkan dengan pembelajaran model NHT memperoleh hasil nilai rata-rata sebesar 85,52 dengan $S D=7,98$. Hal ini juga tampak pada peningkatan rata-rata hasil belajar siswa pretest $(40,89)$ ke posttest $(79,78)$ dengan pembelajaran model Jigsaw, sedangkan dengan pembelajaran model NHT peningkatan rata-rata hasil belajar siswa pretest $(46,57)$ ke posttest $(85,52)$. Dari hasil perhitungan uji-t diperoleh thitung $>$ ttabel $(3,48$ $>$ 1,665) maka $\mathrm{H}_{\mathrm{a}}$ diterima dan $\mathrm{H}_{0}$ ditolak. Dengan demikian dapat diketahui bahwa hasil belajar siswa pada kelas NHT lebih tinggi dari hasil belajar kelas Jigsaw. Maka dapat disimpulkan bahwa ada perbedaan yang signifikan hasil belajar siswa menggunakan model pembelajaran kooperatif tipe Jigsaw dengan NHT pada Materi Sistem Pernapasan Manusia di kelas XI IPA MAN 1 Medan T.P 2017/2018.

Berdasarkan hasil pengamatan di kelas Jigsaw menunjukkan bahwa siswa saling berbagi ilmu dengan teman sekelompoknya dari materi yang sudah dipelajarinya di kelompok asal. Hal ini menuntut siswa untuk mengingat materi yang telah didiskusikan terlebih dahulu sebelum memberi tahu kepada teman-temannya. Namun ketika sedang berdiskusi terdapat perbedaan persepsi antar siswa dalam memahami konsep materi yang telah didiskusikan, sehingga membuat siswa yang memiliki tingkat kepercayaan diri yang kurang akan takut untuk menyampaikan materi yang sudah diperoleh dari hasil diskusi kelompok asal. Pendalaman materi yang dilakukan siswa juga kurang efektif karena waktu yang tersedia hanya sedikit, sehingga menyebabkan siswa belum menguasai materi sepenuhnya dari materi yang sudah diberikan guru. Sesuai dengan pendapat
Putra dan Hartati (2014), bahwa model pembelajaran kooperatif tipe Jigsaw memiliki kekurangan yaitu : (a) Perbedaan persepsi siswa dalam memahami suatu konsep; (b) Siswa cenderung sulit meyakinkan siswa lain bila percaya diri yang dimiliki siswa tersebut kurang; (c) Guru cenderung membutuhkan waktu yang lama untuk merekap hasil belajar siswa berupa nilai dari kepribadian siswa; (d) Membutuhan waktu yang cukup lama untuk menguasai model pembelajaran ini.

Penerapan model pembelajaran NHT di kelas XI IPA ${ }^{4}$ menunjukkan bahwa siswa saling bekerja sama dan bertukar pikiran untuk menjawab kuis yang diberikan guru. Siswa juga memiliki rasa tanggung jawab untuk memperdalam materi agar tidak diintimidasi oleh teman sekelompoknya dan tidak mengecewakan anggota kelompok apabila siswa tersebut yang akan bertanggung jawab terhadap nilai kelompoknya. Sesuai dengan penelitian Munawaroh (2015), menyatakan bahwa model pembelajaran kooperatif tipe NHT dapat meningkatkan hasil belajar siswa dengan nilai pretest sebesar 79,76 dan meningkat pada nilai postest sebesar 91,73. Penelitian Kurniasih dan Sani (2016), menyatakan bahwa model pembelajaran kooperatif tipe NHT memiliki kelebihan yaitu: (a) Dapat meningkatkan prestasi belajar siswa; (b) Mampu memperdalam pemahaman siswa; (c) Melatih tanggung jawab siswa; (d) Meningkatkan rasa percaya diri siswa; (e) Mengembangkan rasa saling memiliki dan kerjasama; (f) Setiap siswa termotivasi untuk menguasai materi.

Aktivitas yang diamati dalam penelitian ini adalah 1) aktivitas melihat; 2) aktivitas berbicara; 3) aktivitas mendengar dan 4) aktivitas menulis. Berdasarkan data aktivitas siswa yang diamati observer selama pembelajaran di kelas Jigsaw dan NHT diketahui bahwa dari keempat aktivitas yang diamati, aktivitas yang paling dominan adalah aktivitas melihat dan mendengar. Aktivitas melihat yang diamati yaitu membaca materi pelajaran dan memperhatikan penjelasan guru, sedangkan aktivitas mendengar yang diamati yaitu mendengarkan penjelasan guru dan penjelasan (pendapat) teman. Aktivitas melihat siswa lebih 
banyak terlihat di kelas NHT (110) sedangkan pada kelas Jigsaw $(105,3)$, sebab pada kelas NHT siswa lebih banyak yang membaca materi pelajaran untuk menjawab pertanyaan LKPD yang diberikan guru dan memperhatikan penjelasan guru agar bisa mengikuti proses pembelajaran dengan baik. Sejalan dengan penelitian Maman dan Rajab (2016), menyatakan bahwa model pembelajaran kooperatif tipe NHT dapat meningkatkan kemampuan siswa dalam memahami membaca dengan rincian pada siklus I memperoleh $44 \%$ siswa yang dikategorikan sangat baik sedangkan pada siklus II diperoleh $84 \%$ yang dikategorikan sangat baik. Aktivitas mendengar siswa lebih banyak terlihat di kelas NHT $(106,7)$ sedangkan pada kelas Jigsaw $(104,4)$, sebab pada kelas NHT siswa lebih banyak mendengarkan penjelasan dari guru dan temannya dikarenakan seluruh siswa harus dapat bertanggung jawab dalam menjawab pertanyaan dari guru mengenai materi pelajaran yang sudah dijelaskan oleh guru dan teman sekelompoknya.

Penerapan model pembelajaran Jigsaw di kelas XI IPA ${ }^{2}$ menunjukkan bahwa aktivitas siswa di dalam kelas dapat meningkat dengan nilai sebesar 84,67 dengan kategori baik. Hal ini dikarenakan pada model pembelajaran Jigsaw siswa dituntut untuk saling berbagi materi yang sudah dipahami dari kelompok ahli, sehingga siswa akan lebih aktif untuk berbicara dalam penyampaian materi kepada teman di kelompok asal dan anggota yang lainnya mendengarkan. Penelitian sebelumnya juga dilakukan oleh Sari, D dan Djulia, E (2016), menunjukkan bahwa penerapan model pembelajaran Jigsaw dapat meningkatkan aktivitas belajar siswa dengan memperoleh nilai rata-rata $66,11 \%$ dengan kategori cukup aktif. Sejalan dengan penelitian Hidayah, $d k k$ (2017) menunjukkan bahwa ketika diberi pengajaran dengan model Jigsaw pada siklus I terdapat $12 \%$ siswa dengan kategori aktif, pada siklus II terdapat 36\% kategori aktif dan semakin meningkat pada siklus III terdapat $76 \%$ dengan kategori aktif.

Penerapan model pembelajaran NHT di kelas XI IPA ${ }^{4}$ menunjukkan bahwa aktivitas siswa dapat meningkat dengan nilai sebesar 88,29 dengan kategori sangat baik. Sesuai dengan penelitian yang dilakukan oleh Gultom dan Sinaga, E (2016), menunjukkan bahwa penerapan model pembelajaran NHT dapat meningkatkan aktivitas belajar siswa yaitu pada aktivitas melihat memperoleh nilai 80,46 , aktivitas berbicara 77,01 , aktivitas mendengar 81,61 dan aktivitas menulis 86,78 sehingga memperoleh nilai rata-rata keseluruhan aktivitas adalah 81,47 dengan kategori aktif. Hasil penelitian sebelumnya juga dilakukan oleh Berutu dan Sinaga, E (2017), menyatakan bahwa pengajaran dengan menggunakan model NHT pada kelas XI IPA semua siswa terlibat aktif dalam pembelajaran dan saling bekerja sama satu sama lain untuk memecahkan masalah yang tertera dalam LKPD.

\section{SIMPULAN}

Terdapat perbedaan yang signifikan antara hasil belajar dan aktivitas siswa menggunakan model pembelajaran kooperatif tipe Jigsaw dengan NHT pada materi Sistem Pernapasan Manusia di kelas XI IPA MAN 1 Medan T.P 2017/2018 pada $\alpha=$ 0,05 .

\section{UCAPAN TERIMA KASIH}

Ucapan terima kasih penulis ucapkan kepada Ibu Kepala Sekolah MAN 1 Medan, kepada Bapak/lbu guru Biologi yang sudah membantu serta seluruh siswa di MAN 1 Medan.

\section{DAFTAR PUSTAKA}

Berutu, N.A., dan Sinaga, E., (2017), Perbedaan Hasil Belajar Siswa Menggunakan Model Pembelajaran Kooperatif Tipe Numbered Head Together Dengan Snowball Throwing Pada Sub Materi Struktur Dan Fungsi Sel Di Kelas XI SMA, Jurnal Pelita Pendidikan, Vol 5(1):073-080.

Gultom, T.L.E., dan Sinaga, E., (2016), Perbedaan Hasil Belajar Dan Aktivitas Siswa Dengan Pembelajaran Model Kooperatif Two Stay Two Stray (TSTS) Dan Numbered Head Together (NHT) Pada Materi Sistem Pernapasan Manusia Kelas XI IPA SMA Swasta Parulian 1 Medan, Jurnal Pelita Pendidikan, Vol 4(4):058-064.

Hasruddin, (2009), Memaksimalkan Kemampuan Berpikir Kritis Melalui Pendekatan 
Kontekstual, Jurnal Tabularasa, Vol 6(1).

Hidayah, N.A.W., Suharno., Indriayu, M., (2017), The Use of Cooperative Learning of Jigsaw-Type and Make a Match Type to Improve Students' Activity, International Journal of Recent Engineering Science (IJRES), Vol 4(1).

Jumiati., Sari, M., Akmalia, D., (2011), Peningkatan Hasil Belajar Siswa Dengan Menggunakan Model Numbereds Heads Together (NHT) Pada Materi Gerak Tumbuhan Di Kelas VII SMP Sei Putih Kampak, Jurnal Lectura, Vol 02. No 02.

Kurniasih, I., dan Sani, B., (2016), Ragam Pengembangan Model Pembelajaran, Kata Pena, Jakarta.

Maman, M., dan Rajab, A.A., (2016), The Implementation of Cooperative Learning Model 'Numbered Heads Together (NHT)' in Improving the Students' Ability in Reading Comprehension, International Journal of Evaluation and Research in Education (IJERE), Vol 5(2):174-180.

Munawaroh, (2015), The Comparative Study Between The Cooperative Learning Model Of Numbered Heads Together (NHT) and Student Team Achievement Division (STAD) to The Learning Achievement in Social Subject, IQSR Journal of Research \& Method in Education (IOSR-JRME), Vol 5(1):24-23.

Putra, S.D., dan Hartati, Y.C.S., (2014), Penerapan Model Pembelajaran Kooperatif Tipe Jigsaw Terhadap Hasil Belajar Chest Pass Pada Permainan Bola Basket (Studi pada Siswa Kelas VII SMP Negeri 5 Sidoarjo), Jurnal Pendidikan Olahraga dan Kesehatan, Vol 2(3):526-531.

Sari, D.P., dan Djulia, E., (2017), Perbedaan Hasil Belajar Dan Aktivitas Siswa Menggunakan Model Pembelajaran Tipe Jigsaw Dan Tipe Role Playing Pada Materi Sistem Peredaran Darah Manusia Kelas XI IPA SMAN 3 Pematang Siantar, Jurnal Pelita Pendidikan, Vol 6(1):047-053.

Sudjana, (2002), Metode Statistika, PT. Tarsito, Bandung.

Trianto, (2009), Mendesain Model Pembelajaran Inovatif-Progresif, Kencana, Bandung.

Wahyuningsih, D., dan Murwani, S., (2015), Peningkatan Aktivitas Dan Hasil Belajar
Siswa Pada Pembelajaran Biologi Melalui Implementasi Model Numbered Head Together Pada Siswa Kelas XI SMA Negeri 2. 